from the Department of Health, the special trustees of Guy's Hospital, and Bayer, UK Limited.

1 Borch-Johnsen K, Andersen PK, Deckert T. The effect of proteinuria on relative mortality in type 1 (insulin-dependent) diabetes mellitus. Diabetologia 1985;28:590-6.

2 Krolewski AS, Kosinski EJ, Warram JH, et al. Magnitude and determinants of coronary artery disease in juvenile-onset, insulin-dependent diabetes mellitus. Am f Cardiol 1987;59:750-5.

3 Viberti GC, Hill RD, Jarrett RJ, Argyropoulos A, Mahmud U, Keen H. Microalbuminuria as a predictor of clinical nephropathy in insulindependent diabetes mellitus. Lancet 1982;i:1430-2.

4 Mathiesen ER, Oxenbell B, Johansen K, Svendsen PA, Deckert T. Incipient nephropathy in type 1 (insulin-dependent) diabetes. Diabetologia 1984;26: 406-10.

5 Parving HH, Oxenboll B, Svendsen PA, Sandahl-Christiansen J, Andersen AR. Early detection of patients at risk of developing clinical nephropathy. A longitudinal study of urinary albumin excretion. Acta Endocrinol 1982;100: 550-5

6 Mogensen CE, Christensen CK. Predicting diabetic nephropathy in insulin dependent patients. $N$ Engl f Med 1984;311:89-93.

Mogensen CE. Microalbuminuria predicts clinical proteinuria and early mortality in maturity onset diabetes. $N$ Engl $\mathcal{F}$ Med 1984;6:356-60.

8 Jarrett RJ, Viberti GC, Argyropoulos A, Hill RD, Mahmud U, Murrells TJ. Microalbuminuria predicts mortality in non-insulin dependent diabetes. Diabetic Med 1984;1:17-9.

9 Mattock MB, Keen H, Viberti GC, et al. Coronary heart disease and urinary albumin excretion rate in type II (non-insulin-dependent) diabetic patients. Diabetologia 1988;31:82-7.

10 Yudkin JS, Forrest RD, Jackson CA. Microalbuminuria as predictor of vascular disease in non-diabetic subjects. Islington diabetes survey. Lance 1988;ii:530-3.

11 Cruickshank JK, Andersen NM, Haines AP. "Spot" urinary albumin creatinine: a positive independent relation to systolic blood pressure in the general population: an index of vascular risk. Clin Sci 1987;72(suppl 16):43.

12 Winocour PH, Durrington PN, Ishola M, Anderson DC, Cohen H. Influence of proteinuria on vascular disease, blood pressure, and lipoproteins in insulin dependent diabetes mellitus. Br Med $\mathcal{F}$ 1987;294:1648-51.

13 Jensen T, Stender S, Deckert T. Abnormalities in plasma concentrations of lipoproteins and fibrinogen in type I (insulin-dependent) diabetic patients with increased urinary albumin excretion. Diabetologia 1988;31:142-5.

14 Vannini P, Ciavarella A, Flammini M, et al. Lipid abnormalities in insulindependent diabetic patients with albuminuria. Diabetes Care 1984:7:151-4.

15 Fuller JH, Keen $\mathrm{H}$, Jarrett RJ, et al. Haemostatic variables associated with diabetes and its complications. Br Med f 1979;ii:964-6.

16 Kwaan HC, Colwell JA, Cruz S, Suwanwela N, Dobbie JG. Increased platelet aggregation in diabetes mellitus. $\mathcal{F}$ Lab Clin Med 1972;80:236-46.

17 Wiseman MJ, Viberti GC, Mackintosh D, Jarrett RJ, Keen H. Glycaemia, arterial pressure and micro-albuminuria in type 1 (insulin-dependent) diabetes mellitus. Diabetologia 1984;26:401-5.

18 Microalbuminuria Collaborative Study Group, England. Sex, diabetes duration and microalbuminuria in IDDM. Diabetes and Metabolism 1988;14 $183-4$

19 Caerphilly and Speedwell Collaborative Group. Caerphilly and Speedwell collaborative heart disease studies. F Epidemiol Community Health 1984;38 259-62.

20 Yarnell JWG, Fehily AM, Millbank JE, Sweetnam PH, Walker CL. A shor dietary questionnaire for use in an epidemiological survey: comparison with weighed dietary records. Hum Nutr Appl Nutr 1983;37A:103-12.

21 Veall N, Gibbs GP. The accurate determination of tracer clearance rates and equilibrium distribution volumes from single injection plasma measurements using numerical analysis. In: Joekes AM, ed Radionuclides in nephrology. London: Academic Press, 1982:125-30.

22 Carlson K. Lipoprotein fractionation. F Clin Pathol 1973;26(suppl 5):32-7.

3 Warnick GR, Benderson J, Albers JJ. Dextran sulphate-Mg2 + precipitation procedure for quantitation of high-density lipoprotein cholesterol. Clin Chem 1982;28:1379-88.

24 Pietri A, Dunn FL, Raskin P. The effect of improved diabetic control on plasma lipid and lipoprotein levels. A comparison of conventional therapy and continuous subcutaneous insulin infusion. Diabetes 1980;29:1001-5.

25 Tamborlane WV, Sherwin RS, Genel M, Felig P. Restoration of normal lipid and aminoacid metabolism in diabetic patients treated with a portable insulin-infusion pump. Lancet 1979;i:1258-61.

26 Lopes-Virella MF, Wohltmann HJ, Loadholt CB, Buse MG. Plasma lipids and lipoproteins in young insulin-dependent diabetic patients: relationship with control. Diabetologia 1981;21:216-23.

27 Felts JM, Mayerle JA. Urinary loss of plasma high density lipoprotein-a possible cause of hyperlipidaemia of the nephrotic syndrome. Circulation 1974;50(suppl 3):263.

28 Short CD, Durrington PN, Mallick NP, Hunt LP, Tetlow L, Ishola M. Serum and urinary high density lipoproteins in glomerular disease with proteinuria. Kidney Int 1986;29:1224-8.

29 Shore VG, Forte T, Licht H, Lewis SB. Serum and urinary lipoproteins in the human nephrotic syndrome: evidence for renal catabolism of lipoproteins. Metabolism 1982;31:258-68.

30 Gordon T, Castelli WP, Hjortland MC, Kannel WB, Dawber TR. High density lipoprotein as a protective factor against coronary heart disease. The Framingham study. Am f Med 1977;62:707-14.

31 Durrington PN, Ishola M, Hunt L, Arrol S, Bhatnagar D. Apolipoproteins (a), AI and B and parenteral history in men with early onset ischaemic heart disease. Lancet 1988 ; i: 1070-3.

32 Meade TW, Mellows S, Brozovic M, et al. Haemostatic function and ischaemic heart disease. Principal results of the Northwick Park heart study. Lancet 1986;ii:533-7.

33 Stone MC, Thorpe JM. Plasma fibrinogen-a major coronary risk factor. $f R$ Coll Gen Pract 1985; 35:565-9.

34 Feldt-Rasmussen B. Increased transcapillary escape rate of albumin in type 1 (insulin-dependent) diabetic patients with microalbuminuria. Diabetologic 1986;29:282-6.

35 Williamson JR, Chang K, Tilton RG, et al. Increased vascular permeability in spontaneously diabetic $\mathrm{BB} / \mathrm{W}$ rats and in rats with mild versus severe streptozotocin-induced diabetes. Diabetes 1987;36:813-21.

36 Bent-Hanson L, Deckert T. Metabolism of albumin and fibrinogen in type (nsulin-dependent) diabetes mellitus. Diabetes Res 1988;7:159-64.

37 Lyons TJ, Klein RL, Baynes JW, Stevenson HC, Lopes-Virella MF. Stimulation of cholesteryl ester synthesis in human monocyte-derived macrophages by low-density lipoproteins from type 1 (insulin-dependent) diabetic patients: the influence of non-enzymatic glycosylation of lowdiabetic patients: the influence of non-enzymatic
density lipoproteins. Diabetologia 1987;30:916-23.

38 Lopez-Virella MF, Sherer GK, Lees AM, et al. Surface binding, internalisation and degradation by cultured human fibroblasts of low density lipoproteins isolated from type 1 (insulin-dependent) diabetic patients: changes with metabolic control. Diabetologia 1982;22:430-6.

39 Moorhead JF, Chan MK, El-Nahas M, Varghese Z. Lipid nephrotoxicity in chronic progressive glomerular and tubulo-interstitial disease. Lancet 1982 ii: $1309-1$

40 French SW, Yamanaka W, Ostwald R. Dietary induced glomerulosclerosis in the guinea pig. Arch Pathol 1967;83:204-10.

41 Al-Shebeb T, Frohlich J, Magil AB. Giomerular disease in hypercholestero guinea pigs: a pathogenetic study. Kidney Int 1988;33:498-507.

(Accepted 9 December 1988$)$

\title{
Transplants from living donors in the United Kingdom and Ireland: a centre survey
}

\author{
P K Donnelly, D G Clayton, A R Simpson
}

\begin{abstract}
Departments of Surgery and Community Health, University of Leicester P K Donnelly, FRCS, senior lecturer in surgery D G Clayton, PHD, senior lecturer in medical statistics

Transplant Unit, Leicester General Hospital,

Leicester LE5 4PW

A R Simpson, SRN, transplant coordinator
\end{abstract}

Correspondence to: $\mathrm{Mr} \mathrm{P} \mathrm{K}$ Donnelly, Department of Surgery, Leicester General Hospital, Leicester

LE5 4PW.

\section{Abstract}

A survey was carried out to determine for the first time the extent of transplantation from living donors in the United Kingdom and Republic of Ireland and the views of transplant surgeons regarding future developments. Questionnaires were sent to 32 transplant centres representing 18 health regions and covered their extent of experience of transplantation, sources of donors, ages of donors and recipients, outcome of transplantation, and views on expansion of living donor transplantation services. Replies received from 27 transplant centres representing 17 health regions gave data on more than 1200 transplants from living donors. Transplants from living donors accounted for $0-25 \%$ of the total experience of health regions. Two centres had abandoned living donor transplantation. Sixty per cent of transplant surgeons favoured expansion of the living donor programme to meet a shortage of kidneys from cadavers, and the remainder thought that existing programmes were optimal.

Living donor transplantation promises to be an important factor in the future planning of health care resources.

\section{Introduction}

When reviewing kidney transplantation in Leicester during 1987 we found a reduction in the number of transplants (table) consequent on a diminishing supply of donor organs despite vigorous campaigns to encourage organ donation. No transplantations from living donors had been performed in the area since 1984 even though seven of the eight previous recipients had functioning grafts. Possible reasons for the decline in transplantations from living donors were the excellent survival of patients with grafts from cadavers after treatment with cyclosporin, uncertainty over the long 
Number of patients receiving organ transplants in Leicester, 1975-87

\begin{tabular}{lcc}
\hline & $\begin{array}{c}\text { From } \\
\text { cadavers }\end{array}$ & $\begin{array}{c}\text { From } \\
\text { living donors }\end{array}$ \\
\hline 1975 & 5 & \\
1976 & 6 & \\
1977 & 13 & \\
1978 & 17 & 1 \\
1979 & 10 & \\
1980 & 17 & \\
1981 & 14 & \\
1982 & 28 & 1 \\
1983 & 41 & 1 \\
1984 & 43 & 5 \\
1985 & 38 & \\
1986 & 51 & \\
1987 & 38 & \\
\hline
\end{tabular}

term effects of nephrectomy in donors, and the expectation that most patients would get a kidney from a cadaver soon after starting dialysis. In our review we found that patients received dialysis for an average of two years before transplantation.

Before considering an expansion of our living donor transplantation programme we decided to check how other centres were coping with this problem and first contacted the United Kingdom Transplant Service. Though it did not have a register of data on living donor transplants, it confirmed that the plateau in the supply of kidneys from cadavers and increasing demand for transplants in Leicester were reflected in national statistics. ${ }^{12}$

National comparisons can be made of living donor transplantation within Europe. ${ }^{3}$ Of the 14000 kidneys transplanted in the United Kingdom, $10-12 \%$ have been from live donors. Countries in Europe vary enormously in their use of living donor transplantation to cope with their waiting lists for transplants. Often the percentage of kidneys from living donors is influenced by cultural and religious views or the acceptance of criteria for brain death. In Greece and Turkey living donors supply $60-90 \%$ of all transplants, whereas in Spain they supply $6 \%^{3}$; in the United States living donors supply $32 \%$ of all transplants. ${ }^{45}$ In view of these large differences we conducted a survey of living donor transplantation among centres in the British Isles.

\section{Methods}

In July 1987 questionnaires were sent to 32 transplant centres in 17 health regions in the United Kingdom and to the Republic of Ireland. The following topics were covered: date of first transplantation from a living donor; extent of transplantation experience; source of donors; ages of donors and recipients; outcome of transplantations; and views on expansion of the living donor transplantation programme. As there was no readily available information on the catchment area for donors for each renal transplant unit the centres were asked to define their boundaries.

Analysis of survival of grafts was complicated by the fact that the date of failure had not always been accurately recorded. The construction of survival curves based on such data has been discussed by Peto. ${ }^{6}$ Our method was similar to that advocated by Peto but reduced computation time by grouping the time scale. As most centres did not separate technical failures from those due to rejection all failures were grouped together. Grafts that were functioning when patients died were regarded as lost to follow up.

\section{Results}

Of the 32 transplant centres contacted, 27 replied, representing 17 health regions (including the Republic of Ireland). The data that were supplied varied enormously among centres but represented over 1200 transplants. Seven transplant centres gave information on transplants from living donors only as a percentage of their total transplants (including some transplants for temporary residents), and one centre gave a cumulative result for survival of 334 transplants from living donors. Altogether 654 transplantations were recorded in sufficient detail to permit analyses of source of donor and length of survival.

Though transplantation from living donors was first performed in Edinburgh and London in 1960, by far the greatest experience ( 334 transplants since 1968) has been in the south Thames area, based mainly on the transplant units of Guy's and Dulwich Hospitals. The next largest centre was Dublin with 134 transplants, followed by Liverpool (119) and Newcastle upon Tyne (110). Two transplant units, Leicester and Sheffield, had abandoned living donor transplantation in favour of transplants from cadavers. The regional difference in experience of transplantation from living donors is best illustrated by the geographical distribution of the procedure (fig 1). It accounted for up to $25 \%$ of total transplantations among health regions, the lowest figures being found in the Midlands.

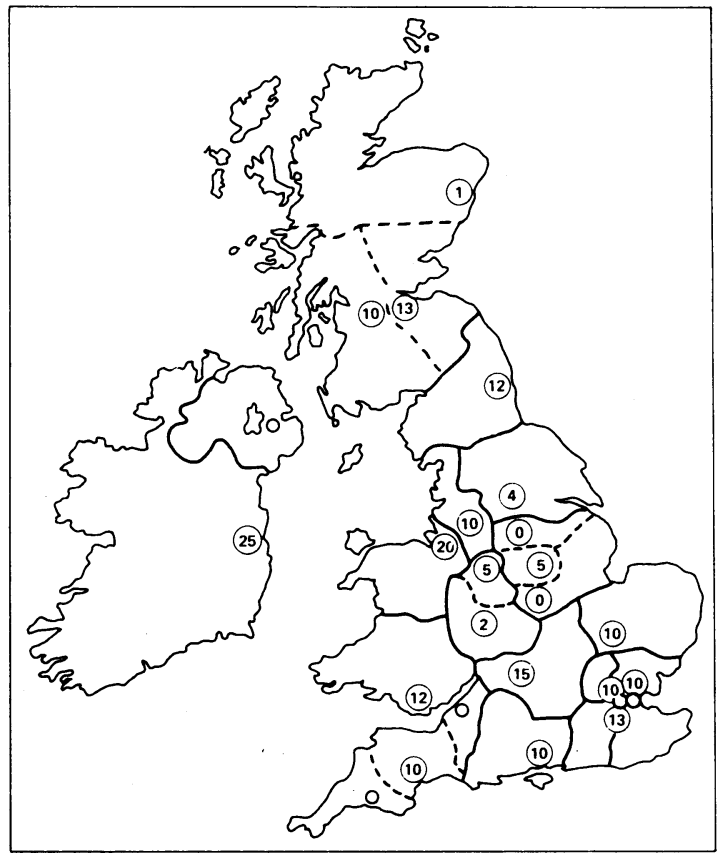

FIG 1-Transplantation centres and their catchment areas. Circle indicate locations of centres; numbers within circles are percentage of living donor transplantations performed each year. Figures for the Thames areas include 11 transplant centres. Replies from South

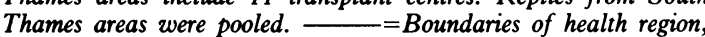
$---=$ boundaries of catchment area of centre

Of the 654 transplants from living donors, most were from the siblings $(369 ; 56 \%)$, parents $(249 ; 38 \%)$, and children $(16 ; 2 \%)$ of recipients. The relationship of seven $(1 \%)$ donors was unknown, and five twins, three uncles or aunts, one niece, and four unrelated donors represented $<1 \%$ each of transplants.

Though the ages of most recipients were known, the ages of less than half of the donors had been recorded. Most recipients were aged 25-34, as were the donors, although the overall trend was for donors to be older than recipients.

Survival was based on known survival time in 102 of

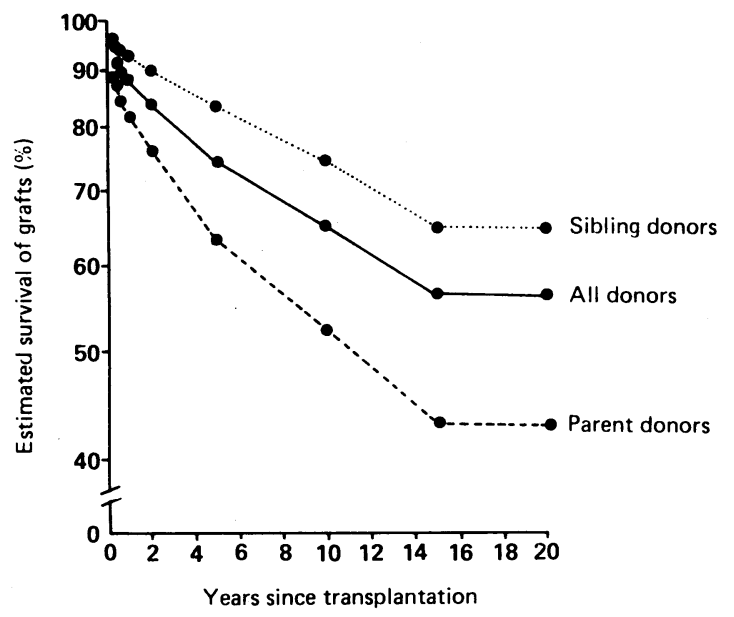

FIG 2-Estimated survival of kidney grafts from all, sibling, and parent living donors. Estimates based on known survival time in 102 of 142 failures among 609 transplants 
142 failures among 609 cases for which we had information. Figure 2 shows that an estimated $89 \%$ of grafts survived after one year, $76 \%$ after five years, and $66 \%$ after 10 years. Long term graft survival was better for kidneys donated by siblings than by parents. Data were insufficient for us to construct survival curves for grafts from other groups of donors. The worst results were among the recipients aged under 24 , and results were surprisingly good in recipients aged over 49 (fig 3).



FIG 3-Estimated survival of kidney grafts from living donors according to age of recipient. Estimates based on known survival time in 102 of 142 failures among 609 transplants

Centres were invited to comment on the expansion of living donor transplantation. Most (60\%) centres commented that it should be expanded to cope with the shortfall of kidneys from cadavers. Some centres stated limitations: one would consider living donor transplantation only for children and another only for identical twins, though two centres were considering transplantation from unrelated donors, usually spouses.

\section{Discussion}

Although the information requested in this survey was not detailed, the response is comparable with that in recent American studies. ${ }^{5}$ Our findings reinforce recent recommendations for better data on availability of donors within different district health authorities. The Department of Health does not have an accurate map of the catchment areas of each transplant unit. Though many transplant centres cover an area that coincides with the boundaries of the health district, some do not. We believe that our map (fig 2) is the first compilation of areas for retrieval of cadavers as recognised by transplant coordinators. With the emergence of smaller transplant centres the renal unit may treat patients from a large district and the regional neurosurgical unit may lie in a separate district, as is the case for Leicester. Organs are shared equitably as a result of a local rather than a national agreement. Transplant centres that have a large population receiving dialysis but lack a major donor centre because of geographical boundaries may need to make greater use of living donor transplantation if waiting lists are to be kept to reasonable levels.

A great deal can be learnt from a collaborative experience in transplantation. Even from our limited analysis it was clear that grafts from siblings fare much better in the long term than those from parents, which confirms the findings in large series in the United States and Europe.$^{89}$ Poor long term survival of grafts was found among younger recipients (aged under 24).
The relative age difference between donor and recipient may be important in future planning. Few centres were prepared to transplant a child's kidney to an adult, and most sibling donors had an age difference of no more than 10 years from their recipient. Centres may favour different matching and treatment regimens, such as donor specific transfusion. ${ }^{10}$ An awareness of these differences among centres has been of benefit in transplantation from cadavers, and information should clearly be shared if transplantation from living donors is to expand more widely. ${ }^{11}{ }^{12}$

If living donor transplantation is to be more widely accepted then both doctors and patients need to be familiar with its potential benefits and hazards. The advantages may be seen as excellent survival of grafts, short waiting time, and a cost saving to the NHS Despite the advances in immunosuppressive treatment over the past 20 years the survival of transplants from cadavers with cyclosporin treatment is only now approaching the one year survival of $80-90 \%$ obtained with transplants from living donors. ${ }^{13}$

The excellent long term results of living donor transplantation shown in this study $(60 \%$ survival at 20 years) is in contrast to the poor long term results predicted for transplants from cadavers in patients treated with azathioprine and cyclosporin. ${ }^{14}$ National statistics show that many patients wait more than two years for a reasonably matched kidney from a cadaver. ${ }^{14}$ Prolonged dialysis is expensive both financially and in terms of hardship to the family. ${ }^{1516}$ A successful transplant saves the NHS $£ 30000,{ }^{17}$ and on average it costs less than $£ 500$ for routine investigations (for example, intravenous urography, renal arteriography) of a potential donor. ${ }^{18}$

The disadvantages of living donor transplantation have been well established in American series and relate mainly to the risk of mortality or morbidity in the donor. ${ }^{19-21}$ Though one in 1600 donors die after nephrectomy, ${ }^{5}$ this risk has been estimated to be less than that of dying from a road traffic accident. Postoperative morbidity has been estimated to be 1$2 \%$, the main problems being deep venous thrombosis, pulmonary embolism, and wound infection. ${ }^{11820}$ The longer term consequences of donating a kidney have been investigated intensively over the past few years. ${ }^{22-25}$ Recent reviews of 25 years of follow up found no significant risk to the donor in surviving with a single kidney provided that recognised criteria for selection had been used. ${ }^{524} 25$ Though proteinuria has been found in one third of donors, it is non-progressive and believed to be related to hereditary factors. ${ }^{5}$ Only two of almost 10000 living donors have been reported to have developed end stage renal failure. ${ }^{24}$

An expansion of living donor transplantation could take place in two stages. Firstly, relatives could, depending on their cultural and religious views, be routinely screened as possible donors. Secondly, family members other than blood relatives could be considered as a source of kidneys. The prospect of using an unrelated living donor has been widely discussed in recent years, but the debate that rightly outlawed payment for transplantation cast a shadow over the ethics of expanding living donor transplant programmes. ${ }^{26} 27$

The spouse most commonly carries the burden of the ailing patient and has most to gain from the wellbeing that a successful transplant restores. Recent studies suggest that spouse to spouse kidney transplantation with combined immunosuppressive treatment can result in excellent graft function. ${ }^{28}$ In the United States $16 \%$ of transplant centres surveyed used living donors who were not blood relatives; $40 \%$ were prepared to consider spouse to spouse donation. ${ }^{19}$ Provided that families can be given adequate information and support and donors are carefully selected 
the option of renal transplantation from living donors should be more widely discussed.

We thank the many clinicians and transplant coordinators who contributed to this survey and Mrs Carole Austin, who typed the manuscript.

\footnotetext{
1 Bradley BA, Selwood NH. The natural history of transplantable kidneys. Health Trends 1983;15:25-7.

2 United Kingdom Transplant Service. Annual report. Bristol: UKTS, 1988.

2 United Kingdom Transplant Service. Annual report. Bristol: UKTS, 1988. Nephrol Dial Transplant 1987;2:475-87.

4 US end stage renal disease program: selected 1984 statistics. Contemporary Dialysis and Nephrology 1985;12:11.

5 Bay WJ, Lee AH. The living donor in kidney transplantation. Ann Intern Med 1987; 106:719-27.

6 Peto R. Experimental survival curves for interval-censored data. Applied Statistics 1973;23:86-91

7 Working Party on the Supply of Donor Organs for Transplantation. Report. London: Department of Health and Social Security, 1987.

8 Morris PJ. Results of renal transplantation. In: Morris PJ, ed. Kidney transplantation. London: Academic Press, 1984:547-9.

9 Brunner FP, Broyer M, Bryner H, et al. Survival on renal replacement therapy: data from the EDTA registry. Nephrol Dial Transplant 1988;2: 109-22.

10 Salvatieria D, Vincetti F, Amend $\mathrm{W}$, et al. Deliberate donor-specific blood transfusions prior to living related renal transplantation. Ann Surg 1980;192: transfusion.

11 Taylor RMR, Ting A, Briggs JD. Renal transplantation in the United Kingdom and Ireland - the centre effect. Lancet 1985; ; :798-802.

2 Anonymous. Living related kidney donors [Editorial]. Lancet 1982;ii:696.

13 Kahan BD, Mickey R, Flechner SM, et al. Multivariate analysis of risk
}

factors impacting on immediate and eventual cadaver allograft survival in cyclosporin-treated recipients. Transplantation 1987;43:65-70.

14 Gilks WR, Bradley BA, Gore SM. Predicting waiting time for a beneficially matched graft. Transplant Proc 1987;19:3640-1.

15 Kutner NG, Brogan D, Kutner MH. End-stage renal disease treatment modality and patients' quality of life. Am $\mathcal{F}$ Nephrol 1986;6:396-402.

16 Maher ER, Curtis JR. Mortality and morbidity of long term haemodialysis. Lancet 1987; ;:452-3.

17 Wood IT, Mallick NP, Wing AJ. Prediction of resources needed to achieve the national target for treatment of renal failure. Br Med $\mathcal{Y} 1987 ; 294: 1467-70$.

18 Sherwood T, Riutu M, Chisholm GD. Renal angiography problems in live kidney donors. Br f Radiol 1978;51:99-105.

19 Spital A, Spital M, Spital R. The living kidney donor. Arch Intern Med 1986;146:1993-6.

20 Ogden DA. Consequences of renal donation in man. Am $\mathcal{f}$ Kidney Dis 1983;2:501-11.

21 Weiland D, Sutherland DER, Chaveris B, Simmons RL, Ascher NL, Najarian JS. Information on 628 living related kidney donors at a single institutio with long term follow-up in 472 cases. Transplant Proc 1984;16:5-7.

22 De Marco T, Amin M, Harty JJ. Living donor nephrectomy: factors influencing morbidity. $\mathcal{O}$ Urol 1982;127:1082-3.

23 Davison JM, Uldall PR, Walls J. Renal function studies after nephrectomy in renal donors. Br Med f 1976; i: 1050-2.

24 Tapson JS. Prognosis after donor nephrectomy: an update. Int $\mathcal{f}$ Artif Organs 1987;10:9-13.

25 Tapson JS, Mansy H, Marshall SM, Tisdall SR, Wilkinson R. Renal functional reserve in kidney donors. $Q \mathcal{F}$ Med 1986;232:725-32.

26 Morris PJ, Sells RA. Paying for organs from living donors. Lancet 1985; i: 1510 . 27 Council of the Transplantation Society. Commercialisation in transplantation: the problems and some guidelines for practice. Lancet 1985;ii:715-6.

28 Haberdal M, Sert S, Aybasti N, et al. Living donor kidney transplantation. Transplant Proc 1988;20:353-5.

(Accepted 23 November 1988

\section{Human gastric mucosal bleeding induced by low dose aspirin, but not warfarin}

Peter J Prichard, Gerry K Kitchingman, Robert P Walt, Tawfique K Daneshmend, Christopher J Hawkey

\section{Abstract}

Objective-To investigate the suitability of treatment with low dose aspirin or warfarin, or both, as possible prophylaxis against cardiovascular disease by determining the effect on gastric mucosal bleeding.

Design-Randomised crossover trial.

Setting-Academic department of therapeutics.

Subjects-Twenty healthy male volunteers aged 19-22.

Interventions-On separate occasions and in randomised order all subjects received aspirin $75 \mathrm{mg}$, warfarin, or aspirin $75 \mathrm{mg}$ combined with warfarin. Each treatment was given for 12 days or (when warfarin was used) for longer if necessary until the international normalised ratio of the prothrombin time was stable at 1.4-1.6.

End point-Loss of blood over 10 minutes into gastric washings.

Measurements and main results-Bleeding over 10 minutes into gastric washings under baseline conditions and after five days, and at end of each regimen of treatment. Aspirin $75 \mathrm{mg}$ increased bleeding from 0.60 (95\% confidence interval 0.36 to 0.99$) \mu \mathrm{l} / 10$ minutes to $1.26(0.71$ to 2.25) $\mu \mathrm{l} / 10$ minutes at five days, with no evidence of either progressive change or adaptation thereafter. Warfarin had no effect on bleeding either alone or when combined with aspirin.

Conclusions-Aspirin $75 \mathrm{mg}$ causes gastric mucosal bleeding. Low dose warfarin neither induces gastric mucosal bleeding nor enhances that caused by aspirin.

\section{Introduction}

Thrombosis is a common feature of both unstable angina and death from ischaemic heart disease and unstable angina. This may be related to enhanced platelet activity ${ }^{2}$ or increased amounts of fibrinogen and factor VII, which have been associated with fatal and non-fatal ischaemic heart disease. ${ }^{3-6}$ The effect that aspirin has on the function of platelets has been shown to reduce morbidity and mortality in patients with unstable angina and myocardial infarction and to be probably beneficial in the primary and secondary prevention of myocardial infarction. ${ }^{7-20}$ Trials have tended to use progressively lower doses of aspirin as these cause maximum inhibition of synthesis of thromboxane by platelets, have a minimal effect on synthesis of prostacyclin by vessel walls, and substantially prolong the bleeding time..$^{21-23}$ For these reasons doses of aspirin of less than $100 \mathrm{mg}$ a day might theoretically be more effective than higher doses, but for the same reasons they might render patients prone to bleeding that is also seen with higher doses. ${ }^{7-20}$

Anticoagulant treatment with warfarin has also been used to prevent myocardial reinfarction. Although it is probably beneficial, ${ }^{24}$ its continued use causes a progressive increase in bleeding. ${ }^{25}$ An alternative approach is to use lower doses to normalise the increased activity of factor VII found in patients prone to vascular disease,${ }^{6}$ but whether this would cause less bleeding is as yet unproved.

Possibly optimum benefit would accrue from combining low doses of aspirin and warfarin, and this approach is to be investigated by the Medical Research Council in a large community based study. ${ }^{26}$ Because a combination of treatments has the potential to enhance harm (particularly gastrointestinal bleeding) as much as benefit we investigated the effect of low doses of aspirin and warfarin, alone and in combination, on gastric mucosal bleeding.

\section{Subjects and methods}

Twenty healthy non-smoking male volunteers aged 19 to 22 participated in the study. They did not have a 